\title{
China's Official Development Assistance: An Implication of the Transport Infrastructure Development in Cambodia
}

\author{
Chet Vathanak \\ Techo Sen School of Government and International Relations, University of Cambodia, Phnom Penh, Cambodia \\ Email: chetvathanak@gmail.com
}

How to cite this paper: Vathanak, C. (2021) China's Official Development Assistance: An Implication of the Transport Infrastructure Development in Cambodia. Open Access Library Journal, 8: e7697.

https://doi.org/10.4236/oalib.1107697

Received: June 25, 2021

Accepted: August 24, 2021

Published: August 27, 2021

Copyright $\odot 2021$ by author(s) and Open Access Library Inc.

This work is licensed under the Creative Commons Attribution International License (CC BY 4.0).

http://creativecommons.org/licenses/by/4.0/

\section{(c) (i) Open Access}

\begin{abstract}
China's ODA in Cambodia had been executed since the 1950s with the remarkable evidence of the four factories' construction in Cambodia during the 1960s, while the United States of America had also experienced providing funds to build roads and bridges and other humanitarian reliefs in Cambodia during the 1950s and 1960s. After the national election in 1993, foreign assistance was given to Cambodia to support the economic infrastructure and to fill the gap of government expenditure budgets of each year, since there was a huge amount of the trade balance deficit. China has been the largest donor and investor in Cambodia in exchange for high commitment of the country to support the "One-China Policy" and the Belt and Road initiative right after its commencement in 2013. Since then, Cambodia has received huge amounts of ODA from China in several sectors, especially the transportation infrastructure sector. This research focuses mainly on China's ODA for transportation infrastructure development contributed to the GDP growth of Cambodia by focusing mainly on the public sector foreign aid and ignoring the private sectors (investment scheme). The researcher used a mixed-method to analyze the data collected by using Eviews 10 with the least-squares' method to analyze the data. The research result showed that China's ODA for the transportation infrastructure development in Cambodia significantly contributed to the GDP growth of Cambodia, with the scientific evident chance of occurrence of 99.81 percent, with only a 0.19 percent-chance of error.
\end{abstract}

\section{Subject Areas \\ International Relations}

\section{Keywords}

Official Development Assistance, Transportation Infrastructure Development, 
Gross Domestic Product, Road and Bridge Infrastructure, Airport and Port Infrastructure

\section{Introduction}

Foreign aid or foreign assistance is defined as the international transfer of goods, services, or capital from a country or an international aid agency to the recipient country or its people for three reasons: 1) to compensate for their past wrong, 2) to secure friendships to increase their influences, secure natural resources to cope up with their economic growth, and to expand markets for their trade, and 3) to fulfill their international obligation (Quiviger, 2020) [1]. The ODA from the OECD countries rose remarkably to USD 161.2 billion (OECD, n.d.) [2], while China's ODA was estimating to go lower than USD 5.9 billion in 2020 (Kitano \& Miyabayashi, 2020) [3].

Cambodia is a small and poor country located in the heart of ASEAN, was extremely invaded by neighboring countries since the 15 century, and was badly affected by World War I, World War II, the Cold War, the French Colonization, the Vietnam War and the Civil War for few decades. Again in the 1970s, Cambodia had fallen into civil war until the 1990s. After the Paris Peace Accord in 1991, Cambodia had become independent and obtained partial peace, and has been obtaining full peace after 1999. Went through those bad times, the human capital, economic and social infrastructure was almost destroyed. To develop the infrastructures, Cambodia had been facing many circumstances, lacking human capital, and saving capital to support the economy and social needs.

Traditional donors like the United States, Japan, Australia, Germany, Sweden, the World Bank, the Asian Development Bank (ADB), the International Monetary Fund (IMF), World Foods Program (WFP), the United Nations Development Program (UNDP), the United Nations for International Children Funds (UNICEF), the United Nations for Agriculture Development Organization (FAO) and some other donors had presented to help Cambodia since the 1980s, especially after the national election in 1993.

The United States of America had provided foreign assistance to Cambodia in the 1960s approximately same amounts with China during the 1950s and the 1960s, and then cut off in response to the request of the former King Norodom Sihanouk (Marsot, 1969) [4]. The United States provided funds as humanitarian assistance to build roads and bridges in Cambodia in the 1960s and currently moved apart from basic human needs to improve health and education services through contracts and grants to private voluntary organizations, International Organizations, and Cambodian-run organizations (USASSISTANCE, 2021) [5].

Cambodia had signed agreements for foreign assistance amounting to USD 1843.47 billion, and USD 1288.27 billion in 2018 and 2019 respectively. Through this information, the Royal Government of Cambodia prioritized many funds to 
the infrastructure development projects which represented $87.12 \%, 85.39 \%$, $63.91 \%$ for 2018,2019 , and 2020 respectively (the researcher calculated based on the data from CPDSB, 2021) [6].

Mutual relations between Cambodia and China has been resumed after the 1991 Paris Peace Accord, and China's Official Development Assistance (ODA) was dramatically increased after 1998 and become the largest donor in Cambodia in 1999, and the largest foreign investor in 2011. China's ODA was reaching USD 5.8 billion, USD 6.1 billion, and 6.4 billion in 2016, 2017, and 2018 respectively (Kitano, 2019) [7], while China's ODA in Cambodia was USD 311.11 million, USD 327.18 million, and USD 644.8 million in 2016, 2017, and 2018 respectively (CPDSB, 2019) [8].

So far until today, China keeps applying the concept of "south-south cooperation" in providing grants or loan funds to recipient countries, and with no strings attached (Jakobson, 2009) [9], and abiding by the principle of "Peaceful Co-existence" (Liu, 2014) [10]. The unconditional loan and assistance of China, in response to the requests of recipient countries (Dreher et al., 2017) [11]. Some recipient countries welcome and expressed their gratitude to China for the positive assistance for their countries, in which many leaders called Beijing "a reliable friend" (Wan, 2018) [12], and Cambodia called "the most trustworthy friend" (Zhou, 2019) [13]; while some recipient countries, scholars, and researchers criticized China for the no string attached to its loan and assistance could be a trap to the recipient countries (Fernholz, 2018) [14] when the countries use the loan or assistance in an ineffective way (Easterly \& Pfutze, 2008) [15]. For instance, Burgos and Ear (2007) [16] viewed that China treats Cambodia as an important partner for the sake of its energy self-sufficiency.

The critics of some researchers on China's ODA as a "rogue aid" (Dreher \& Fuchs, 2015 [17]; Naim, 2009 [18]), on the other hand, some researcher described China's ODA as a loan trap diplomacy or payday-loan-diplomacy, or infrastructure war (Rowley, 2020) [19].

Since controversial concepts around China assistance, and Cambodia leaders and high-ranking officials treat China as the closest friend, there is a question that arises: Does China's ODA helpful for the transport infrastructure development and contributed to the economic growth in Cambodia?

The researcher used mixed methods of quantitative and qualitative in this research and used Eviews 10 to analyze the data by using the least-squares' method. The data collection was conducted for three months from January to March 2021. Most of the data were collected through internet base searches, and collected from newspapers, websites, blogs, bulletins, and the RGC's periodic reports, by focusing on the public sector.

The transportation infrastructure development here refers to the road, bridge, and airport construction, renovation, expansion, and the expansion and capacity upgrading of the ports.

This research is structured as follows. The first section is an introduction, the 
second section is the Background of the study, the third section is China's ODA for the transportation development in Cambodia, and the fourth section is Discussion and Conclusion.

\section{Background of the Study}

\subsection{Why Has Cambodia Been in Need of External Assistance?}

First, confirm that you have the correct template for your paper size. This template has been tailored for output on the custom paper size $(21 \mathrm{~cm} * 28.5 \mathrm{~cm})$.

Had gone through internal conflict and greatly invaded by the neighboring countries for more than four decades since the 15th century, and badly impacted by World War I, World War II, and later on fallen under the French's colonialism since 1863, Cambodia was greatly suffered during those bad periods. Again, during the Cold War Cambodia suffered from the Great Power competitions pushed Cambodia to fall into the Civil War for almost four decades. To restore her economy, Cambodia has struggled for a long time since most of the human, economic and social infrastructures were destroyed, especially lacking saving to develop the country, in which foreign development assistance was the only way to breaking this gap.

Among all donors, only the United States of America and China experienced almost the same period since the 1950s and also the same amounts in providing foreign assistance to Cambodia, but the United States of America cut off their foreign assistance during the 1960s in response to the request of Cambodia (Marsot, 1969) [4]. Moreover, China was the backed supporter of the People Democratic Kampuchea, which 1.7 million people were killed during the evil times (Heng, 2018) [20]. The relations between Cambodia and China were cut off from 1979 to 1990 and have been resumed after the Paris National Peace Accord in 1991.

\subsection{Who Have Been the Main Foreign Aid Providers for Transportation Infrastructure Development in Cambodia?}

After the bilateral relations between the two countries have been reconnected in the 1990s, China has become the largest donor in Cambodia in 1999 for USD 257 million pledging assistance, and the largest investor in Cambodia for the sum investment capital of USD 8.8 billion in 2011 (Heng, 2018) [20]. Since the inception of the Belt and Road initiative by China's leader Xi Jingping in 2013, Cambodia fully supports the initiative BRI and associated projects present great benefits for Cambodia, especially the concrete transport infrastructure and connectivity development have been observed in Cambodia (Sok, 2019) [21].

Only a few donors helped Cambodia to construct and renovate transportation infrastructure including the World Bank, the Asian Development Bank, Japan, and China. China is not only the biggest donor in transportation infrastructure development in Cambodia, but also the largest economic influencer, the largest foreign investor, the largest trading partner, the largest buyer of Cambodian's 
rice, and the largest source of tourist in the country (Sok, 2019) [21].

By 2018, China's ODA in Cambodia was reaching USD 5800 million and the balance or the debt owed to China was USD 3418.91 million. By mid of 2019, China's ODA represented 48 percent of the total foreign debts of Cambodia, totaling USD 7.22 billion (IDI, 2020) [22]. According to the Ministry of Economy and Finance in the updated report of the Cambodia Public Debt Statistical Bulletin (CPDSB), Cambodia owed to China USD 269 million and 317 million in 2019 and 2020 respectively (CPDSB, 2021) [6].

\subsection{Conclusion}

When we are talking about foreign assistance in Cambodia, no one can ignore the presence of China's ODA, since almost fifty percent of the ODA was the contribution of China. China has become the major player in Cambodia both in foreign development assistance and foreign direct investment since 1998, became the largest donor in 1999, and became the largest foreign investment in 2011. Below we look more detail on China's foreign assistance in Cambodia by focusing mainly on the transportation infrastructure development in the country. The accumulated public external debt owed to all donors as of the year-end of 2020 was USD 15,039.14 million, while the amount owed to China was USD 5255.26 million represented 34.94 percent of the total foreign public debt (CPDSB, 2021) [6].

\section{China and the Development of Transport Infrastructure in Cambodia}

The amounts of foreign assistance to Cambodia has been significant growth since 1998 by focusing mainly on the economic infrastructure, and infrastructure projects base on the request and priority of the recipient countries, no string attached, no political pressure, and no internal issues interfere over the recipient countries (The State Council Information Office of the People Republic of China, 2011 [23]; 2014 [24]; 2021 [25]).

Cambodia road infrastructure comprises more than 44,000 kilometers, almost 12 percent is a national road, more than 14 percent in the provincial road, and almost 75 percent in the rural or territory road. Along each road, there are some small or medium scale bridges, and there are 16 large-scale bridges were constructed and put into operations as of 2020. There are four airports are operating in Phnom Penh, Siem Reap, Sihanoukville, and Koh Kong. But there are four more airports to be constructed soon like Battambang airport, Mondulkiri airport, Kampong Chhnaing airport, and Poipet airport. Among all the transportation infrastructure of Cambodia, China has funded to construct more than 3000 kilometers of national roads, 8 large-scale bridges, for a length of 8200 meters. China has equipped some technical equipment and enlarged the capacity of the Sihanouk Autonomous Port and the Phnom Penh Autonomous Port.

The transportation improvement projects are crucial for Cambodia, that why 
the Royal Government of Cambodia is regarded as the fundamental issues and prioritize for submission loan funds and grants. Upon the requests of the RGC, China's ODA in Cambodia for infrastructure development has become significant since 1998, and as of 2020, total amounts of USD 6.38 billion were executed in several sectors and out of the amounts 72.57 percent went to the transportation infrastructure development amounting to USD 4.63 billion to build 3381 kilometers of roads, 8200 meters of large scale bridges and five airport and port projects. The 24 projects of road construction and renovation amounting to USD 2.3 billion, 8 large-scale bridge projects amounting to USD 0.76 billion, and 5 airport and port development projects amounting to USD 1.57 billion.

Base on the report of the World Bank, more than 75 percent of the road structure in Cambodia are rural road, and only $5 \%$ of the roads were paved (Bou \& Keyes, 2020), but base on the research finding of Chet Vathanak, 8 percent of the national roads and provincial roads were paved as of 2020 (Chet, 2021) [26].

\subsection{Road and Bridge Infrastructure Development}

Base on the data from the CDC, Cambodia's transportation infrastructure combines of 44,709 kilometers road network, comprising 5263 kilometers, 6441 kilometers, and 33,005 kilometers of the national roads, provincial roads, and territory roads respectively (CDC, n.d.) [27].

Chet Vathanak cited from the (Fresh News, 2021) [28] Cambodia has borrowed loan funds from China for transportation infrastructure development amounting to USD 2.8 billion as of April 2021, and used USD 2.5 billion to construct 29 lines of roads for the length of 2888 kilometers, and 8 large-scale bridges for the length of 8200 meters (Chet, 2021) [26].

By 2020, China has helped to construct new national roads and to repairs existing roads for more than $3000 \mathrm{~km}$ approximately $57 \%$ of all national roads, including 1-digit, 2-digit, 3-digit, and 4-digit national roads (Thou, 2020) [29].

According to the definition set by the Ministry of Public Works and Transports of Cambodia, China helped to construct and renovate roads in Cambodia at least 24 projects by focusing mainly on the national roads with one and two digits, and the provincial roads. The data showed that China financed $60 \%$ and $54 \%$ for construction and renovation of the national road with one and two digits respectively, and contributed $61 \%$ if we combined the national roads with one and two digits together. China contributed only $3 \%$ to construct and renovate provincial roads in Cambodia. Further, if we combined all national roads with one digit and two digits with provincial roads, China contributed 31\% to the road construction and renovation in Cambodia. Overall, China has contributed to financing $8 \%$ of road construction and renovation in Cambodia from 2003 to 2019.

Among the sixteen large-scale bridges in Cambodia, China funded to construct eight bridges represented 50 percent of all large-scale bridges in Cambodia. Among all funds financed to build those bridges, concessional loans represented 
almost 98 percent and another more than 2 percent as an interest-free loan, with total loan amounts of more than USD 718 million from 2003 to 2019. The distributions of China represented 50 percent of the total large-scale bridges in Cambodia in terms of numbers, and 47 percent in terms of lengths.

\subsection{Airport and Port Infrastructure Development}

Through the research and observation of the researcher, there were four airports and 2 ports were financed by China's ODA for the construction, expansion, capacity upgrading, and technical equipment. The said four airports including the construction of the new international airport of Phnom Penh, the construction of the new international airport in Koh Kong (Dara Sakor airport), the expansion of Siem Reap international airport, and the construction of the new airport in Mondolkiri. China's ODA for ports including the container scanning machines supplied to the Preah Sihanouk Autonomous Port, and the expansion of the Phnom Penh Autonomous Port. As of 2020, the total of China's ODA for the airport and port development in Cambodia amounting to USD 2.35 billion (Table 1).

The regression runs in Eviews 10 with the least-squares method and the result interpret in the model of:

Table 1. China's ODA for transportation development in Cambodia.

\begin{tabular}{|c|c|c|}
\hline Year & CNODA & GDP \\
\hline 2003 & $28,800,000$ & $4,658,246,918$ \\
\hline 2004 & $15,971,612$ & $5,337,833,248$ \\
\hline 2005 & - & $6,293,046,162$ \\
\hline 2006 & - & $7,274,595,707$ \\
\hline 2007 & $215,837,248$ & $8,639,235,842$ \\
\hline 2008 & $545,504,492$ & $10,351,914,093$ \\
\hline 2009 & $103,748,196$ & $10,401,851,851$ \\
\hline 2010 & $61,869,606$ & $11,242,275,199$ \\
\hline 2011 & $262,384,868$ & $12,829,541,141$ \\
\hline 2012 & $239,664,225$ & $14,054,443,213$ \\
\hline 2013 & $94,827,653$ & $15,227,991,395$ \\
\hline 2014 & $156,627,530$ & $16,702,610,842$ \\
\hline 2015 & $145,623,188$ & $18,049,954,289$ \\
\hline 2016 & - & $20,016,747,754$ \\
\hline 2017 & $862,144,928$ & $22,177,200,512$ \\
\hline 2018 & $1,129,012,130$ & $24,571,753,583$ \\
\hline 2019 & $3,004,347,826$ & $27,089,389,787$ \\
\hline Total & $6,866,363,501$ & $234,918,631,536$ \\
\hline
\end{tabular}

(Source: The researcher used the collected data from (the World Bank, n.d. [30]; Macrotrends, n.d. [31]) and other relevant sources to generate the table using Pivot Table in Ms. Excel 2013 spreadsheet). 


$$
\mathrm{GDP}=\mathrm{a}+\mathrm{b} \text { CNODA }+\mathrm{e}
$$

Through the result, the equation of the regression model can be illustrated as:

$$
\mathrm{GDP}=1.12+6.388 \mathrm{CNODA}
$$

If CNODA increases by 1 unit then the GDP increases by 6.388 units, assuming the economy comprises of only one factor, with the chance of error of 0.19 percent (less than 5 percent). Since the chance of error ( 0.19 percent $)$ is less than 5 percent, the independent variable (CNODA) is significant. On the other hand, the probability of the F-statistic is also equal to 0.19 percent is less than 5 percent, the correlation between the independent and dependent variables is significant, so the regression result is significant (Table 2 and Figure 1).

Table 2. The correlation between CNODA and GDP in Cambodia.

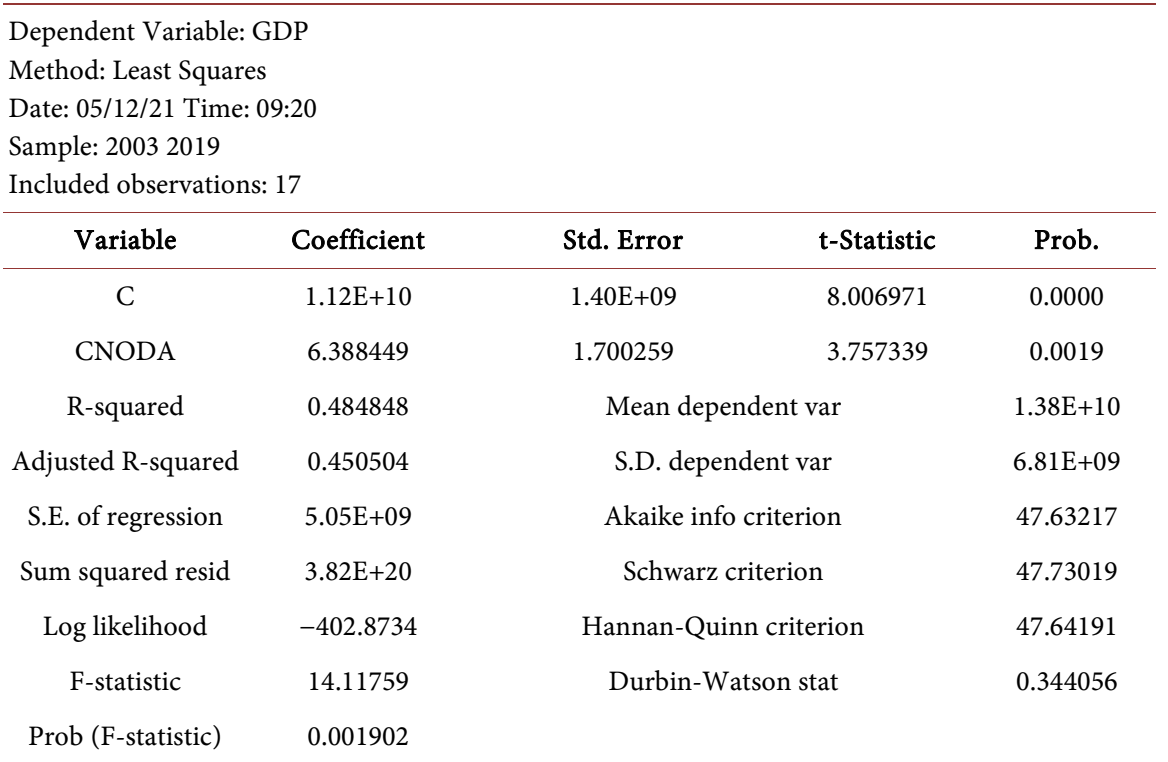

(Source: The researcher generated the table from Eviews 10).

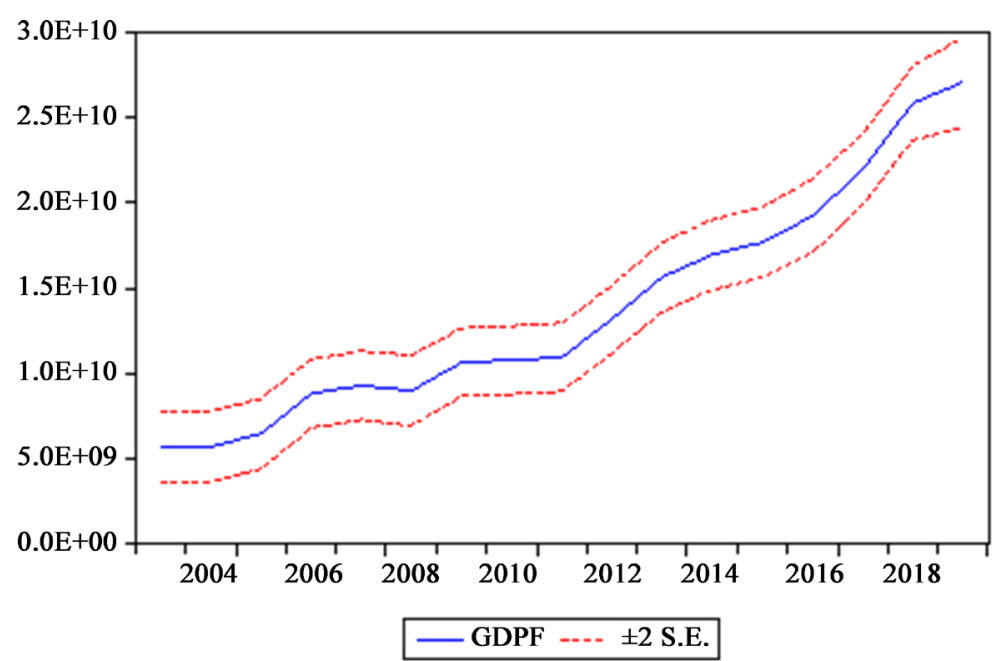

Forecast: GDPF

Actual: GDP

Forecast sample: 20032019

Included observations: 17

Root Mean Squared Error $\quad 8.76 \mathrm{E}+08$

Mean Absolute Error

Mean Abs. Percent Error $\quad \mathbf{6 . 8 4 7 8 8 3}$

Theil Inequality Coefficient $\mathbf{0 . 0 2 8 6 1 4}$

Bias Proportion $\quad 0.000000$

Variance Proportion $\quad 0.004434$

Covariance Proportion 0.995566

Theil U2 Coefficient $\quad 0.743151$

Symmetric MAPE

6.712516

(Source: The researcher generated the graph from data collected by using Eviews 10).

Figure 1. The Projection of GDP growth affected by the CHODA. 


\section{Discussion and Conclusions}

The transport infrastructure is the main channel to boost up economic growth and alleviate poverty in all countries, especially Cambodia. Significant evidence of the help of China's ODA in Cambodia remarkably in the stable economic growth of Cambodia after 1998 the same period with China's ODA growth steadily and became the main funder and investor in Cambodia. With the productive help from China and other related donors including the World Bank, ADB, Japan, South Korea, almost 4000 kilometers of road were paved, about 10 kilometers of large-scale bridges long were already constructed and renovated, and some more bridges along the national and provincial roads were also constructed and renovated.

Base on the above information, about 30 percent of the national roads and provincial roads in Cambodia were paved and renovated under the fund support from China's ODA, 50\% percent of large-scale bridges in Cambodia were constructed under the fund support from China's ODA, and almost all construction and expansion projects of airport and port in Cambodia were also implemented under the financial support from China.

The research result can be summarized that China's ODA significantly contributed to the economic growth in Cambodia with the chance of happening of 99.81 percent, keeping the other factors remain constant.

The researcher strongly supported the well-known Economist Jeffrey Sachs that China's ODA breaking the shortage of savings in Cambodia, and helped to boost up and stabilize the economic growth in Cambodia. There was no enough evidence to support the William Easterly concept since the transport infrastructure development in Cambodia much contributed to the economic growth and fairly contributed to the rich and the poor in the country.

Further studies should be conducted on the effectiveness of China's ODA and its composition in Cambodia, especially to clarify the doubtful statement "infrastructure war" raised by Anthur Culvahouse, the former Ambassador of the United States of America to Australia.

\section{Conflicts of Interest}

The author declares no conflicts of interest.

\section{References}

[1] Quiviger, W. (2020, February 6) What Is Foreign Aid and Does It Work? IE School of Global and Public Affairs.

https://www.ie.edu/school-global-public-affairs/faculty-and-research/ie-explains/fo reign-aid-work/\#: :text=Foreign\%20aid\%20is\%20assistance\%20given,tracking\%20 mechanism\%20for\%20this\%20aid

[2] OECD (n.d.) Development Assistance Committee (DAC). OECD Homepage. https://www.oecd.org/dac/development-assistance-committee

[3] Kitano, N. and Miyabayashi, Y. (2020) Estimating China's ODA: 2019-2020 Preliminary Figures. JICA Ogata Sadako Research Institute for Peace and Development 
Tokyo, December 14, 2020.

[4] Marsot, A.G. (1969) China's ODA to Cambodia. Pacific Affairs, 42, 189-198.

[5] USASSISTANCE (2021, March 4) History. USASSISTANCE, Home "Where We Work "Asia" Cambodia" History. https://www.usassistance.gov/cambodia/history

[6] CPDSB (2021, March) Cambodia Public Debt Statistical Bulletin, Volume 11. The Ministry of Economy and Finance. Phnom Penh.

[7] Kitano, N. (2019, September 27) Estimating China's Foreign Aid: 2017-2018 Preliminary Figures. JICA Research Institute, Tokyo. https://www.jica.go.jp/jica-ri/publication/other/175nbg000018z3zd-att/20190926_01 $\underline{\mathrm{pdf}}$

[8] CPDSB (2019, March) Cambodia Public Debt Statistical Bulletin, Volume 7. The Ministry of Economy and Finance, Phnom Penh.

[9] Jakobson, L. (2009) China's Diplomacy toward Africa: Drivers and Constraints. International Relations of the Asia-Pacific, 9, 403-433. https://doi.org/10.1093/irap/lcp008

[10] Liu, Z. (2014) International Colloquium Commemorating the 60th Anniversary of the Five Principles of Peaceful Coexistence. Beijing, May 27, 2014.

[11] Dreher, A., Fuchs, A., Parks, B.C., Strange, A.M. and Tierney, M.J. (2017) Assistance, China, and Growth: Evidence from a New Global Development Finance Dataset. Assistance Data Working Paper \#46. Assistance Data, Williamsburg. https://doi.org/10.2139/ssrn.3051044

[12] Wan, F. (2018, May 15) How “Unconditional” Is China's ODA? DW Made for Minds. How "Unconditional” Is China's Foreign Assistance? Asia. An In-Depth Look at News from across the Continent. DW. 15.05.2018.

[13] Zhou, T. (2019) A Blend of "Hard" and "Soft" Assistance: China's Assistance to Cambodia. In: Huang, M., et al., Eds., South-South Cooperation \& Chinese Foreign Assistance, Palgrave Macmillan, Singapore, 95-111.

https://doi.org/10.1007/978-981-13-2002-6_7

[14] Fernholz, T. (2018, March 8) Eight Countries in Danger of Falling into China's "Debt Trap". QUARTZ, Port Authority.

https://qz.com/1223768/china-debt-trap-these-eight-countries-are-in-danger-of-de bt-overloads-from-chinas-belt-and-road-plans

[15] Easterly, W. and Pfutze, T. (2008) Where Does the Money Go? Best and Worst Practices in Foreign Assistance. Journal of Economic Perspectives, 22, 29-52. https://doi.org/10.1257/jep.22.2.29

[16] Burgos, S. and Ear, S. (2010) China's Strategic Interests in Cambodia-Influence and Resources. Asian Survey, 50, 615-639. https://doi.org/10.1525/as.2010.50.3.615 http://online.ucpress.edu/as/article-pdf/50/3/615/77157/as_2010_50_3_615.pdf

[17] Dreher, A. and Fuchs, A. (2015) Rogue Assistance? An Empirical Analysis of China's Assistance Allocation. The Canadian Journal of Economics, 48, 988-1023. http://www.jstor.org/stable/43818241 https://doi.org/10.1111/caje.12166

[18] Naim, M. (2009, October 15) Rogue Assistance: What's Wrong with the Foreign Assistance Programs of China, Venezuela, and Saudi Arabia? They Are Enormously Generous. And They Are Toxic. Foreign Policy, Missing Links. https://foreignpolicy.com/2009/10/15/rogue-assistance

[19] Rowley, A. (2020, November 25) The Myth of China's Debt-Trap Diplomacy. NIKKEI Asia. 
https://asia.nikkei.com/Opinion/The-myth-of-China-s-debt-trap-diplomacy

[20] Heng, P. (2018, August 29) Are China's Gifts a Blessing or a Curse for Cambodia? East Asia Forum, Economics, Politics and Public Policy in East Asia and the Pacific. https://www.eastasiaforum.org/2018/08/29/are-chinas-gifts-a-blessing-or-a-curse-fo r-cambodia

[21] Sok, K. (2019, April 30) Belt and Road in Cambodia: The Belt and Road in Cambodia: Successes and Challenges. The Diplomat. It's Time for the BRI to Incorporate a More Participatory and Inclusive Approach in Cambodia. https://thediplomat.com/tag/belt-and-road-in-cambodia

[22] IDI (2020) Briefing Paper: Reassessing China's Investment Footprint in Cambodia August 2020. Inclusive Development International.

[23] The State Council Information Office of the People's Republic of China (2011, April 21) China's Foreign Aid (White Paper).

https://www.asienhaus.de/upload/pdf/nachrichten/2011-04-21Chinas-ForeignAidWhitePaper.pdf

[24] The State Council Information Office of the People's Republic of China (2014, July 10) China's Foreign Aid 2014.

http://english.www.gov.cn/archive/white_paper/2014/08/23/content_281474982986 592.htm

[25] The State Council Information Office of the People's Republic of China (2021, January 10) China's International Development Cooperation in the New Era.

http://english.www.gov.cn/archive/whitepaper/202101/10/content_WS5ffa6bbbc6d 0f72576943922.html

[26] Chet, V. (2021) China's Foreign Aid for Road and Bridge Construction in Cambodia. Global Scientific Journals, 9, 224-252.

[27] CDC (n.d.) Road. CDC Homepage.

http://www.cambodiainvestment.gov.kh/investors-information/infrastructure/roads $\underline{. h t m l}$

[28] Fresh News (2021, April 24) Special Report: How China’s \$3B Assistance Assists Cambodia's Roads and Bridges (Video Inside).

http://www.en.freshnewsasia.com/index.php/en/localnews/15229-2019-09-07-03-03 $-43 . \mathrm{html}$

[29] Thou, V. (2020, December 6) Over 3,000 km of Roads Funded by China Loans, Says the Minister. The Phnom Penh Post.

https://www.phnompenhpost.com/business/over-3000km-roads-funded-china-loan $\underline{\text { s-says-minister }}$

[30] The World Bank (n.d.) GDP Growth (Annual \%)—Cambodia: World Bank National Accounts Data, and OECD National Accounts Data Files. https://data.worldbank.org/indicator/NY.GDP.MKTP.KD.ZG?locations=KH

[31] Macrotrends (n.d.) Cambodia GDP Growth Rate 1994-2021. https://www.macrotrends.net/countries/KHM/cambodia/gdp-growth-rate 